Poznań

\title{
Cechy wizerunku politycznego a emocje w głosowaniu na Bronisława Komorowskiego i Jarosława Kaczyńskiego w wyborach prezydenckich w 2010 roku. Raport z badań postaw politycznych studentów
}

\footnotetext{
$\mathbf{P}$
}

ojęcie wizerunku uznawane jest we współczesnym marketingu politycznym za jedno z kluczowych dla wyjaśniania preferencji politycznych i zachowań wyborczych jednostek. Czasem jednak wymyka się ono z ram analizy naukowej, stając się niejako fetyszem, który pozornie pozwala określić skomplikowane przesłanki powstawania decyzji wyborczej. W klasycznych ujęciach wizerunku politycznego (Dennis Nimmo, Roland Savage $)^{1}$ podkreśla się jego trójelementową strukturę: komponent poznawczy, emocjonalny i konatywny. Zarówno owa struktura, jak i przekonanie, iż emocje są w niej czynnikiem najsilniej determinującym, wskazuje na podobieństwo do postawy. W gruncie rzeczy więc, wizerunek polityczny jest (w zamierzeniach jak najsprawniej wykreowanym) komunikatem (obrazem) mającym wywierać pożądane reakcje w obszarze wiedzy, emocji i ekspresji postawy (zachowania). Można by przyjać, iż na płaszczyźnie kognitywnej należy wytworzyć obraz pozytywnych cech charakteru kandydata. Przełoży się on na pobudzenie sympatii dla niego, a w konsekwencji na pragnienie uaktywnienia tej postawy w postaci zachowania wyborczego. Kreowanie wizerunku politycznego powinno zatem polegać na uwypuklaniu cech osobowościowych kandydata, które mogą w określonym docelowym segmencie elektoratu wzbudzać pozytywne emocje. Jednocześnie należy neutralizować takie cechy, które mogłyby kształtować przeciwne emocje. Oczywiście trzeba brać pod uwagę przesłanki tworzenia wizerunku wynikające $\mathrm{z}$ teorii atrybucji ${ }^{2}$. Po pierwsze, jednostka będzie starała się znaleźć powody, dla których kandydat zachowuje się w określony sposób? Po drugie, zachowania społecznie aprobowane dają mało użytecznych informacji o cechach kandydata w przeciwieństwie do działań nieoczekiwanych i zaskakujących. Po trzecie, co wynika z tzw. sześcianu atrybucyjnego Harolda H. Kelleya, spójność kształtowanego wizerunku jest głównym czynnikiem przekonującym wyborcę o cechach kandydata.

Empiryczna analiza wpływu cech wizerunku politycznego na postawy polityczne nakazuje wyciągać nieco skromniejsze wnioski dotyczące siły tego wpływu. Przeprowadzone badania, które są podstawą tego artykułu, nie potwierdzają w sposób bezwarunkowy tezy o jednoznacznej determinacji emocji wyborcy przez cechy wizerunkowe kandydata. Tym bardziej, iż determinującymi bodźcami poparcia dla danego polityka (czy ugrupowania politycznego) mogą być negatywne emocje, które budzi jego rywal. Może należy zatem postrze-

\footnotetext{
${ }^{1}$ D. Nimmo, R. Savage, Candidates and Their Images: Concepts, Methods and Findings, Goodyear 1976.

${ }^{2}$ Szerzej: W. Cwalina, A. Falkowski, Marketing polityczny. Perspektywa psychologiczna, Gdańsk 2006, s. $156-159$.
} 
gać kształtowanie wizerunku politycznego jako mityczną strukturę poznawczą, w której równie ważne miejsce w narracji jak bohater opowieści zajmuje jego antyteza, antybohater ${ }^{3}$.

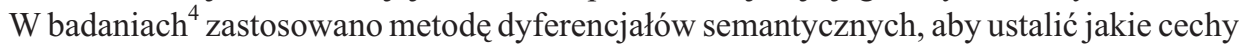
wizerunku politycznego studenci przypisują dwóm głównym kandydatom na Prezydenta Rzeczypospolitej Polskiej w wyborach z 2010 roku: Bronisławowi Komorowskiemu i Jarosławowi Kaczyńskiemu.

W pierwszej kolejności dokonano analizy literatury, aby ustalić jakie cechy brano pod uwagę we wcześniej prowadzonych na ten temat badaniach ${ }^{5}$. Na etapie przygotowawczym, w październiku 2011, przedstawiono studentom listę przymiotników opisujących liderów głównych partii politycznych oraz kandydatów na prezydenta RP. Na podstawie przeprowadzonej analizy czynnikowej wyróżniono - z większej listy przymiotników - 9 par przeciwstawnych cech takich jak: sympatyczny-niesympatyczny, silny-słaby, opanowany-wybuchowy, wierzący-niewierzący, przyjacielski-wrogi, poważny-niepoważny, aktywny-pasywny, kierujący się dobrem Polski-kierujący się dobrem własnej organizacji politycznej. Badani określali, na ile wyróżnione pary przymiotników według nich charakteryzują wybranych polityków na skali od 1 do 7. Jeżeli w wyróżnionej parze cech według badanego pierwsza z cech w pełni charakteryzuje określonego polityka zaznacza 1 (następnie 2, 3) jeżeli cecha przeciwna 7 (następnie 6,5), wartością przeciętną jest 4.

Badania właściwe przeprowadzono w listopadzie 2011 wśród 573 studentów pierwszego roku - studiujących kierunki społeczne na poznańskich uczelniach zarówno publicznych, jak i niepublicznych (tj. politologia, pedagogika, stosunki międzynarodowe, dziennikarstwo i komunikacja społeczna, bezpieczeństwo narodowe, psychologia).

W tabeli poniżej przedstawiono średnie nasilenia cech wizerunku politycznego dla badanej grupy bez podziału na wyborców poszczególnych kandydatów, dla grupy wyborców danego polityka i w grupie wyborców jego kontrkandydata.

Tabela 1

Cechy wizerunku politycznego Bronisława Komorowskiego w grupie badanej, w grupie jego wyborców oraz wyborców Jarosława Kaczyńskiego (średnie)

\begin{tabular}{||l|c|c|c||}
\hline Dyferencjały semantyczne & $\begin{array}{c}\text { Średnia w badanej } \\
\text { grupie dla Bronisława } \\
\text { Komorowskiego }\end{array}$ & $\begin{array}{c}\text { Średnia dla Broni- } \\
\text { sława Komorowskiego } \\
\text { w grupie jego } \\
\text { wyborców }\end{array}$ & $\begin{array}{c}\text { Średnia dla Bronisła- } \\
\text { wa Komorowskiego } \\
\text { w grupie wyborców Ja- } \\
\text { rosława Kaczyńskiego }\end{array}$ \\
\hline 1 & 2 & 3 & 4 \\
\hline Sympatyczny-niesympatyczny & 2,67 & 2,22 & 3,95 \\
\hline Silny-słaby & 3,87 & 3,46 & 4,41 \\
\hline Skuteczny-nieskuteczny & 3,79 & 3,41 & 4,66 \\
\hline Opanowany-wybuchowy & 2,37 & 2,14 & 3,12 \\
\hline Wierzący-niewierzący & 2,73 & 2,35 & 3,51 \\
\hline Przyjacielski-wrogi & 2,72 & 2,35 & 3,44 \\
\hline
\end{tabular}

${ }^{3}$ Por. M. Jeziński, Marketing polityczny a procesy akulturacyjne. Przypadek III Rzeczpospolitej, Torun 2004, s. $146-148$.

${ }^{4}$ Wyniki, które posłużą do dokonania analiz stanowią część szerszego projektu badawczego Diagnoza postaw politycznych studentów poznańskich uczelni realizowanego w Wyższej Szkole Nauk Humanistycznych i Dziennikarstwa pod kierunkiem Karoliny Churskiej-Nowak.

${ }^{5}$ K. Korzeniowski, Psychospołeczne uwarunkowania zachowań wyborczych, w: Podstawy psychologii politycznej, red. K. Skarżyńska, Poznań 2002, s. 250-253; W. Cwalina, A. Falkowski, op. cit., s. 166-190. 


\begin{tabular}{||l|c|c|c|}
\hline \multicolumn{1}{|c|}{1} & 2 & 3 & 4 \\
\hline Poważny-niepoważny & 2,75 & 2,51 & 3,34 \\
\hline Aktywny-pasywny & 3,57 & 3,27 & 4,02 \\
\hline $\begin{array}{l}\text { Kierujący się dobrem Polski-kie- } \\
\text { rujący się dobrem własnej organi- } \\
\text { zacji politycznej }\end{array}$ & 3,00 & 2,49 & 3,85 \\
\hline
\end{tabular}

Wizerunek polityczny Bronisława Komorowskiego składa się z takich cech jak: opanowanie, sympatyczność, przyjacielskość, religijność (trzech ostatnich cech nie dostrzegają wyborcy Jarosława Kaczyńskiego). Dymensja o najmniejszym znaczeniu to cechy silny-słaby oraz skuteczny-nieskuteczny.

Tabela 2

Cechy wizerunku politycznego Jarosława Kaczyńskiego w grupie badanej, w grupie jego wyborców i w grupie wyborców Bronisława Komorowskiego (średnie)

\begin{tabular}{||l|c|c|c||}
\hline \multicolumn{1}{|c|}{ Dyferencjały semantyczne } & $\begin{array}{c}\text { Średnia w badanej } \\
\text { grupie dla Jarosła- } \\
\text { wa Kaczyńskiego }\end{array}$ & $\begin{array}{c}\text { Średnia dla Ja- } \\
\text { rosława Kaczyń- } \\
\text { skiego w grupie } \\
\text { jego wyborców }\end{array}$ & $\begin{array}{c}\text { Średnia dla Jaro- } \\
\text { sława Kaczyńskiego } \\
\text { w wyborców Bro- } \\
\text { nisława Komorow- } \\
\text { skiego }\end{array}$ \\
\hline Sympatyczny-niesympatyczny & 5,88 & 5,68 & 5,93 \\
\hline Silny-słaby & 4,70 & 4,32 & 4,55 \\
\hline Skuteczny-nieskuteczny & 5,15 & 4,80 & 5,05 \\
\hline Opanowany-wybuchowy & 5,53 & 5,32 & 5,41 \\
\hline Wierzący-niewierzący & 2,39 & 2,59 & 2,28 \\
\hline Przyjacielski-wrogi & 5,64 & 5,17 & 5,66 \\
\hline Poważny-niepoważny & 3,79 & 3,56 & 3,82 \\
\hline Aktywny-pasywny & 3,81 & 3,63 & 3,73 \\
\hline $\begin{array}{l}\text { Kierujący się dobrem Polski-kierujący się } \\
\text { dobrem własnej organizacji politycznej }\end{array}$ & 4,99 & 4,76 & 4,97 \\
\hline
\end{tabular}

Główne cechy wizerunku politycznego Jarosława Kaczyńskiego to niesympatyczność, wybuchowość, wrogość oraz religijność. Cechy te dostrzegają nie tylko wszyscy badani (bez podziału na wyborców konkretnych kandydatów), ale także wyborcy samego Jarosława Kaczyńskiego. Dymensja o najmniejszym znaczeniu w opisie tego polityka to cechy aktywny-pasywny oraz poważny-niepoważny.

Stosunek emocjonalny do kandydatów oceniany był na podstawie samooceny emocji pozytywnych i negatywnych na skali od 0 do 10 .

Tabela 3

Stosunek emocjonalny wobec Bronisława Komorowskiego w grupie badanej, w grupie jego wyborców oraz wyborców Jarosława Kaczyńskiego (średnie)

\begin{tabular}{||c|c|c|c||}
\hline \multicolumn{1}{|c|}{ Emocje } & $\begin{array}{c}\text { Średnia w badanej gru- } \\
\text { pie dla Bronisława Ko- } \\
\text { morowskiego }\end{array}$ & $\begin{array}{c}\text { Średnia dla Bronisława } \\
\text { Komorowskiego w gru- } \\
\text { pie jego wyborców }\end{array}$ & $\begin{array}{c}\text { Średnia dla Bronisława } \\
\text { Komorowskiego w gru- } \\
\text { pie wyborców Jarosława } \\
\text { Kaczyńskiego }\end{array}$ \\
\hline Emocje pozytywne & 5,24 & 6,03 & 3,61 \\
\hline Emocje negatywne & 2,79 & 2,02 & 4,58 \\
\hline
\end{tabular}


Bronisław Komorowski w badanej grupie wzbudza pozytywne emocje o średniej sile (średnia 5,24). W grupie wyborców Jarosława Kaczyńskiego Bronisław Komorowski wzbudza ambiwalentne emocje.

Tabela 4

Stosunek emocjonalny wobec Jarosława Kaczyńskiego w grupie badanej, w grupie jego wyborców oraz wyborców Bronisława Komorowskiego (średnie)

\begin{tabular}{||c|c|c|c||}
\hline \multicolumn{1}{|c|}{ Emocje } & $\begin{array}{c}\text { Średnia w badanej } \\
\text { grupie dla Jarosława } \\
\text { Kaczyńskiego }\end{array}$ & $\begin{array}{c}\text { Średnia dla Jarosława } \\
\text { Kaczyńskiego w grupie } \\
\text { jego wyborców }\end{array}$ & $\begin{array}{c}\text { Średnia dla Jarosława } \\
\text { Kaczyńskiego w grupie } \\
\text { wyborców Bronisława } \\
\text { Komorowskiego }\end{array}$ \\
\hline Emocje pozytywne & 1,31 & 4,75 & 0,69 \\
\hline Emocje negatywne & 7,78 & 3,51 & 8,62 \\
\hline
\end{tabular}

Emocje, jakie wzbudza Jarosław Kaczyński to głównie emocje negatywne. Nawet w grupie własnych wyborców postawy emocjonalne można określić jako ambiwalentne.

Następnie określono, czy istnieje związek pomiędzy emocjami a cechami wizerunku politycznego, chcąc określić które cechy silniej korelują z emocjami. Dzięki temu można określić jakie cechy konkretnego polityka należy podkreślać prezentując jego wizerunek polityczny (ze względu na związek z pozytywnymi emocjami) - a które (ze względu na związek z negatywnymi emocjami) należy ukryć lub przeformułować.

Tabela 5

Związek pomiędzy cechami wizerunku politycznego Bronisława Komorowskiego a emocjami wobec niego

\begin{tabular}{|c|c|c|c|}
\hline Dyferencjaly semantyczne & rho Spearmana & Emocje pozytywne & Emocje negatywne \\
\hline \multirow[t]{2}{*}{ Sympatyczny-niesympatyczny } & współczynnik korelacji &,$- 574^{* *}$ &, $454^{* *}$ \\
\hline & istotność statystyczna &, 000 &, 000 \\
\hline \multirow[t]{2}{*}{ Silny-słaby } & współczynnik korelacji &,$- 481^{* *}$ &, $447^{* *}$ \\
\hline & istotność statystyczna &, 000 &, 000 \\
\hline \multirow[t]{2}{*}{ Skuteczny-nieskuteczny } & współczynnik korelacji &,$- 562^{* *}$ &, $472^{* *}$ \\
\hline & istotność statystyczna &, 000 &, 000 \\
\hline \multirow[t]{2}{*}{ Opanowany-wybuchowy } & współczynnik korelacji &,$- 364^{* *}$ & $330^{* *}$ \\
\hline & istotność statystyczna &, 000 &, 000 \\
\hline \multirow[t]{2}{*}{ Wierzący-niewierzący } & współczynnik korelacji &,$- 386^{* *}$ & $272^{* *}$ \\
\hline & istotność statystyczna &, 000 &, 000 \\
\hline \multirow[t]{2}{*}{ Przyjacielski-wrogi } & współczynnik korelacji &,$- 562^{* *}$ &, $428^{* *}$ \\
\hline & istotność statystyczna &, 000 &, 000 \\
\hline \multirow[t]{2}{*}{ Poważny-niepoważny } & współczynnik korelacji &,$- 280^{* *}$ & $280^{* *}$ \\
\hline & istotność statystyczna &, 000 &, 000 \\
\hline \multirow[t]{2}{*}{ Aktywny-pasywny } & współczynnik korelacji &,$- 453^{* *}$ &, $388^{* *}$ \\
\hline & istotność statystyczna &, 000 &, 000 \\
\hline \multirow{2}{*}{$\begin{array}{l}\text { Kierujący się dobrem Polski-kierujący się } \\
\text { dobrem własnej organizacji politycznej }\end{array}$} & współczynnik korelacji &,$- 557^{* *}$ & $468^{* *}$ \\
\hline & istotność statystyczna &, 000 &, 000 \\
\hline
\end{tabular}

** Korelacja jest istotna na poziomie 0,01 (dwustronnie). 
Przypisywane Bronisławowi Komorowskiemu cechy wizerunkowe wiążą się w badanej grupie z emocjami wobec niego. Najbardziej istotne cechy dodatnio korelujące z negatywnymi emocjami i ujemnie korelujące z pozytywnymi to: niesympatyczność, nieskuteczność, wrogość, kierowanie się dobrem własnej organizacji politycznej. Dużo mniejsze znaczenie ma brak powagi (współczynnik korelacji -,280 i ,280). Ocena religijności tego polityka także słabo koreluje $\mathrm{z}$ emocjami wobec niego.

Tabela 6

Związek pomiędzy cechami wizerunku politycznego Jarosława Kaczyńskiego a emocjami wobec niego

\begin{tabular}{|c|c|c|c|}
\hline Dyferencjaly semantyczne & rho Spearmana & Emocje pozytywne & Emocje negatywne \\
\hline \multirow[t]{2}{*}{ Sympatyczny-niesympatyczny } & współczynnik korelacji &, 090 &,- 005 \\
\hline & istotność statystyczna & 055 & ,919 \\
\hline \multirow[t]{2}{*}{ Silny-słaby } & współczynnik korelacji &, $120^{*}$ &,- 058 \\
\hline & istotność statystyczna &, 010 & ,207 \\
\hline \multirow[t]{2}{*}{ Skuteczny-nieskuteczny } & współczynnik korelacji &, $101^{*}$ &,- 050 \\
\hline & istotność statystyczna & ,030 &, 277 \\
\hline \multirow[t]{2}{*}{ Opanowany-wybuchowy } & współczynnik korelacji & 060 &,- 038 \\
\hline & istotność statystyczna & , 196 &, 411 \\
\hline \multirow[t]{2}{*}{ Wierzący-niewierzący } & współczynnik korelacji & 090 &,- 031 \\
\hline & istotność statystyczna & 055 &, 500 \\
\hline \multirow[t]{2}{*}{ Przyjacielski-wrogi } & współczynnik korelacji & 053 &, 013 \\
\hline & istotność statystyczna & ,259 &, 776 \\
\hline \multirow[t]{2}{*}{ Poważny-niepoważny } & współczynnik korelacji & ,121 &,- 075 \\
\hline & istotność statystyczna & 010 &, 106 \\
\hline \multirow[t]{2}{*}{ Aktywny-pasywny } & współczynnik korelacji & 050 &,- 038 \\
\hline & istotność statystyczna &, 283 &, 407 \\
\hline \multirow{2}{*}{$\begin{array}{l}\text { Kierujący się dobrem Polski-kierujący się } \\
\text { dobrem własnej organizacji politycznej }\end{array}$} & współczynnik korelacji &, $092^{*}$ &,- 020 \\
\hline & istotność statystyczna &, 048 & ,662 \\
\hline
\end{tabular}

* Korelacja jest istotna na poziomie 0,05 (dwustronnie).

W badanej grupie cechy wizerunku politycznego przypisywane Jarosławowi Kaczyńskiemu nie wiążą się z emocjami wobec niego. Bardzo słabe związki uzyskano pomiędzy pozytywnymi emocjami a: kierowaniem się dobrem Polski, siłą i skutecznością. Korelacje te nie uprawniają jednak do wyciągania jakichkolwiek wniosków.

Następnie zastosowano metodę regresji logistycznej w celu ustalenia czy oddanie głosu na jednego z dwóch głównych kandydatów na prezydenta Rzeczypospolitej Polskiej w 2010 roku wynikało z przypisywania im pozytywnych cech (z tej części analizy usunięto cechy dotyczące religijności kandydatów) czy też z odczuwania wobec nich sympatii. Celem badań było sprawdzenie, czy w podejmowaniu decyzji politycznych większe znaczenie mają emocje czy pozytywne cechy wizerunku politycznego.

Zmienną wynikową w przeprowadzanej analizie jest to, czy ktoś oddał głos na danego kandydata, natomiast zmiennymi objaśniającymi (predykatorami) są postawy emocjonalne i cechy przypisywane kandydatom.

Wyniki przeprowadzonych analiz wskazują, że istotny statystycznie jest związek pomiędzy oddaniem głosu na Bronisława Komorowskiego a pozytywnymi emocjami wobec niego. 
Przypisywanie temu kandydatowi pozytywnych cech nie wiązało się w sposób istotny z oddaniem na niego głosu (Tabela 7).

Tabela 7

Znaczenie sympatii i pozytywnych cech wizerunku politycznego Bronisława Komorowskiego w glosowaniu na tego kandydata

\begin{tabular}{||l|c|c|c|c|c||}
\hline \multicolumn{1}{|c|}{ Komponenty postawy } & B & Wald & df & Istotność & $\operatorname{Exp(B)}$ \\
\hline Sympatia wobec Bronisława Komorowskiego &, 176 & 15,984 & 1 &, 000 & 1,193 \\
\hline $\begin{array}{l}\text { Pozytywne cechy wizerunku politycznego } \\
\text { Bronisława Komorowskiego }\end{array}$ &, 026 & 1,654 & 1 &, 198 & 1,026 \\
\hline
\end{tabular}

Decyzja o oddaniu głosu na Bronisława Komorowskiego związana była z bardziej pozytywną postawą emocjonalną, $\mathrm{W}=15,984, \mathrm{p}<0,001$. Osoby o bardzo pozytywnej emocjonalnej postawie wobec Komorowskiego były o 1,19 bardziej skłonne oddać na niego głos niż osoby o przeciętnej sile pozytywnych emocji wobec niego. Pozytywne emocje wobec tego kandydata zwiększały więc prawdopodobieństwo oddania na niego głosu o 19\%. Po uwzględnieniu sympatii, przypisywane kandydatowi cechy nie wiązały się istotnie z prawdopodobieństwem oddania głosu na Komorowskiego, $\mathrm{W}=1,65, \mathrm{p}=0,198$.

W modelu uwzględniającym zarówno postawy wobec Bronisława Komorowskiego, jak i Jarosława Kaczyńskiego (Tabela 8) uzyskane dane wskazują, że istotne statystycznie znaczenie w głosowaniu na Bronisława Komorowskiego mają emocje wobec obu kandydatów - przypisywane im cechy nie miały znaczenia.

Wyniki prowadzonych analiz dowodzą także, iż łatwiej jest przewidzieć oddanie głosu na Bronisława Komorowskiego ze względu na negatywną postawę emocjonalną wobec jego kontrkandydata niż na podstawie sympatii do niego samego.

Tabela 8

Znaczenie sympatii i pozytywnych cech wizerunku politycznego Bronisława Komorowskiego i Jarosława Kaczyńskiego w glosowaniu na Bronisława Komorowskiego

\begin{tabular}{|l|c|c|c|c|c||}
\hline \multicolumn{1}{|c|}{ Komponenty postawy } & B & Wald & df & Istotność & Exp(B) \\
\hline $\begin{array}{l}\text { Sympatia wobec Bronisława Komorow- } \\
\text { skiego }\end{array}$ &, 128 & 7,221 & 1 &, 007 & 1,137 \\
\hline $\begin{array}{l}\text { Pozytywne cechy wizerunku polityczne- } \\
\text { go Bronisława Komorowskiego }\end{array}$ &, 030 & 1,948 & 1 &, 163 & 1,030 \\
\hline Sympatia wobec Jarosława Kaczyńskiego &,- 181 & 18,294 & 1 &, 000 &, 834 \\
\hline $\begin{array}{l}\text { Pozytywne cechy wizerunku polityczne- } \\
\text { go Jarosława Kaczyńskiego }\end{array}$ &,- 014 &, 688 & 1 &, 407 &, 986 \\
\hline
\end{tabular}

Oddanie głosu na Bronisława Komorowskiego w sposób istotny statystycznie wiązało się z negatywnymi emocjami wobec Jarosława Kaczyńskiego W =18,294, p < 0,001. Antypatia wobec prezesa PiS zwiększała o 16,6\% szansę oddania głosu na Bronisława Komorowskiego.

Wybór na prezydenta Polski tego kandydata wiązał się także z pozytywnymi emocjami wobec niego $\mathrm{W}=7,221, \mathrm{p}=0,007$. Sympatia w porównaniu $\mathrm{z}$ obojętną postawą emocjonalną zwiększała prawdopodobieństwo oddania głosu na Bronisława Komorowskiego o 13,7\%.

Wyniki przeprowadzonych analiz wskazują, że istotny statystycznie jest związek pomiędzy oddaniem głosu na Jarosława Kaczyńskiego a pozytywnymi emocjami wobec niego oraz pozytywnymi cechami, które przypisują mu jego wyborcy (Tabela 9). 
Znaczenie sympatii i pozytywnych cech wizerunku politycznego Jarosława Kaczyńskiego

w glosowaniu na tego kandydata

\begin{tabular}{||l|c|c|c|c|c||}
\hline \multicolumn{1}{|c|}{ Komponenty postawy } & B & Wald & df & Istotność & $\operatorname{Exp(B)}$ \\
\hline Sympatia wobec Jarosława Kaczyńskiego &, 393 & 33,480 & 1 &, 000 & 1,481 \\
\hline $\begin{array}{l}\text { Pozytywne cechy wizerunku politycznego } \\
\text { Jarosława Kaczyńskiego }\end{array}$ &, 086 & 6,954 & 1 &, 008 & 1,090 \\
\hline
\end{tabular}

Decyzja o oddaniu głosu na Jarosława Kaczyńskiego związana była z sympatią, W=33,48, $\mathrm{p}<0,001$. Osoby o bardzo pozytywnej emocjonalnej postawie wobec Kaczyńskiego były 1,48 bardziej skłonne oddać na niego głos niż osoby o przeciętnej sile pozytywnych emocji wobec niego. Sympatia wobec tego polityka zwiększała więc o $48 \%$ szanse na oddanie na niego głosu. Głosowanie na tego kandydata wiązało się także z przypisywaniem mu przez wyborców bardziej pozytywnych cech $(\mathrm{W}=6,954, \mathrm{p}=0,008)$, które o 1,09 zwiększały szanse na oddanie wobec niego głosu.

Stosując model uwzględniający zarówno postawy wobec Bronisława Komorowskiego, jak i Jarosława Kaczyńskiego (Tabela 10) otrzymano wyniki dowodzące, że istotne statystycznie znaczenie w głosowaniu na Jarosława Kaczyńskiego mają sympatia wobec niego i pozytywne cechy, które przypisują mu badani-emocje i cechy przypisywane jego kontrkandydatowi w jej grupie badanej nie miały znaczenia.

Tabela 10

Znaczenie sympatii i pozytywnych cech wizerunku politycznego Bronisława Komorowskiego i Jarosława Kaczyńskiego w głosowaniu na Jarosława Kaczyńskiego

\begin{tabular}{||l|c|c|c|c|c||}
\hline \multicolumn{1}{|c|}{ Komponenty postawy } & B & Wald & df & Istotność & Exp(B) \\
\hline Sympatia wobec Jarosława Kaczyńskiego &, 368 & 29,508 & 1 &, 000 & 1,445 \\
\hline $\begin{array}{l}\text { Pozytywne cechy wizerunku politycznego Jarosła- } \\
\text { wa Kaczyńskiego }\end{array}$ &, 092 & 7,433 & 1 &, 006 & 1,097 \\
\hline Sympatia wobec Bronisława Komorowskiego &,- 092 & 1,348 & 1 &, 246 &, 912 \\
\hline $\begin{array}{l}\text { Pozytywne cechy wizerunku politycznego Bronisła- } \\
\text { wa Komorowskiego }\end{array}$ &, 022 &, 399 & 1 &, 528 & 1,022 \\
\hline
\end{tabular}

Decyzja o głosowaniu na Jarosława Kaczyńskiego podyktowana była sympatią do niego $\mathrm{W}=29,508, \mathrm{p}<0,001$ oraz pozytywnymi cechami, które przypisywali mu badani $\mathrm{W}=7,433$, $\mathrm{p}=0,006$. Należy zaznaczyć, że wysoka sympatia dodaje ponad $44 \%$ prawdopodobieństwa oddania głosu na tego kandydata, a przypisywane mu pozytywne cechy dodatkowe prawie $10 \%$.

W tej grupie badanej wyborcy Jarosława Kaczyńskiego mieli różnorodne postawy emocjonalne i cechy przypisywane Bronisławowi Komorowskiemu więc związek pomiędzy tymi komponentami a oddaniem głosu na Jarosława Kaczyńskiego okazał się nieistotny statystycznie.

\section{Wnioski}

Oceniając cechy wizerunkowe głównych kandydatów badani uznawali, iż Bronisław Komorowski jest opanowany, sympatyczny, przyjacielski i religijny - w opinii swoich wyborców; 
zdaniem ich przeciwników: słaby, nieskuteczny i pasywny. Jarosław Kaczyński określany był zarówno wśród swoich zwolenników, jak i przeciwników przede wszystkim jako: niesympatyczny, wybuchowy, wrogi i religijny. Trudno jest wskazać konkretne cechy, które wpływałyby na pozytywny stosunek emocjonalny.

Wyborcy Jarosława Kaczyńskiego byli skłonni oddawać na niego głos pomimo negatywnej oceny jego cech wizerunkowych. W przypadku pozytywnej oceny, pragnienie oddania na niego głosu wzrastało o ok. 10\%. Jeśli jednak wyborca odczuwał dla niego sympatię prawdopodobieństwo oddania głosu przyrastało o 44\% lub 48\% - w zależności od przyjętego modelu statystycznego. Wydaje się to potwierdzać przekonanie, iż istotnym problemem tego polityka jest nieumiejętność wzbudzania sympatii, a jednocześnie łatwość wzbudzania antypatii. Ta ostatnia jest o tyle istotna, iż silniej stymulowała pragnienie zagłosowania na Bronisława Komorowskiego niż sympatia dla niego. Pojawia się więc zjawisko głosowania negatywnego. Antypatia do antybohatera może silniej kształtować zachowanie wyborcze niż sympatia dla pozornego bohatera. Takiej prawidłowości nie obserwujemy w odwrotnej sytuacji. Antypatia dla Bronisława Komorowskiego nie wpływała istotnie na chęć zagłosowania na Jarosława Kaczyńskiego. Korelacja pozytywnej oceny cech wizerunku i sympatii dla kandydata jest tu zgodna z przewidywaniami.

Istotnym wnioskiem płynącym z przeprowadzonego badania wydaje się konstatacja, iż silniej niż pozytywna ocena przez wyborcę cech wizerunkowych polityka, na decyzję zagłosowania wpływa sympatia wobec niego. Co więcej, negatywna ocena cech nie musi determinować negatywnych emocji. W grupie wyborców Jarosława Kaczyńskiego można zatem dostrzec konieczność redukcji dysonansu poznawczego. Przeprowadzone badania potwierdziły znany w literaturze przedmiotu pogląd, iż sądy poznawcze dotyczące cech wizerunku politycznego kandydata (np. uczciwość, kompetencje) wywierają znacznie słabszy wpływ na preferencje wyborcze niż emocje, jakie wzbudza. Joanna Mandrosz wskazuje, iż nawet identyfikacja partyjna jest gorszym predykatorem jego wyboru niż emocje odczuwane wobec kandydatów ${ }^{6}$. Jest to konsekwencja postępującego procesu personalizacji polityki, jak się okazuje, korzystna dla polityków mniej kontrowersyjnych. Przenosząc na grunt współczesnego marketingu politycznego teorię rezyduów i derywacji Vilfredo Pareto można stwierdzić, iż istotnym jest, aby wyborca pokochał kandydata. Wytłumaczenie (racjonalizację) dlaczego go kocha dorobi sobie już sam.

\section{Bibliografia}

Cwalina W., Falkowski A., Marketing polityczny. Perspektywa psychologiczna, Gdańsk 2006.

Jeziński M., Marketing polityczny a procesy akulturacyjne. Przypadek III Rzeczpospolitej, Torun 2004.

Korzeniowski K., Psychospoleczne uwarunkowania zachowań wyborczych, w: Podstawy psychologii politycznej, red. K. Skarżyńska, Poznań 2002.

Mandrosz J., Czynniki ograniczajace racjonalność pogladów i zachowań politycznych, w: Podstawy psychologii politycznej, red. K. Skarżyńska, Poznań 2002.

Nimmo D., Savage R., Candidates and Their Images: Concepts, Methods and Findings, Goodyear 1976.

${ }^{6}$ J. Mandrosz, Czynniki ograniczajace racjonalność pogladów i zachowań politycznych, w: Podstawy psychologii politycznej, red. K. Skarżyńska, Poznań 2002, s. 177. 
The features of political images and emotions in the voting for Bronisław Komorowski and Jarosław Kaczyński in the 2010 presidential elections. A report from a survey on the political attitudes of students

\begin{abstract}
Summary
In the theory of political marketing the concept of the image appears crucial when explaining electoral preferences and behaviors. This paper presents a survey into the relations between image factors and liking for the main two candidates in the presidential elections in Poland in 2010. It is widely supposed that the assessment of a candidate's image should translate into a definite (positive or negative) emotion towards him or her. An empirical analysis of the influence of political images on political attitudes, however, leads to a slightly more modest conclusion regarding the power of such influence. Surveys do not unconditionally confirm the assumption that voter's emotions are unequivocally determined by a candidate's image, especially as the decisive factors in stimulating support for a given politician (or party) may be provided by negative emotions evoked by his or her rival. The results of the survey do confirm an observation that has already been noted in the literature, that cognitive judgments of a candidate's image have a considerably weaker influence on voter preferences than the emotions he evokes.
\end{abstract}


